Journal of Animal and Veterinary Advances 10 (15): 2028-2031, 2011

ISSN: $1680-5593$

(C) Medwell Journals, 2011

\title{
Determination of Potential Nutritive Value of Sainfoin (Onobrychis sativa) Hays Harvested at Flowering Stage
}

\author{
Mahmut Kaplan \\ Department of Field Crops, Faculty of Seyrani Agriculture, \\ University of Erciyes, Kayseri, Turkey
}

\begin{abstract}
The aim of this study was to determine the potential nutritive value of sainfoin (Onobrychis viciaefolia) hays harvested at flowering stage from Afsin, Tekir, Pazarcik, Baskonus and Kapicam using chemical composition and in vitro gas production technique. Chemical composition including Crude Protein (CP), Neutral Deterg ent Fiber (NDF) Acid Detergent Fiber (ADF), ash Condensed Tannin (CT), Organic Matter Digestibility $(\mathrm{OMD})$ and Metabolisable Energy $(\mathrm{ME})$ were calculated. Gas productions were determined at 0 , $3,6,12,24,48,72$ and $96 \mathrm{~h}$ incubation times and their kinetics were described using the equation $\mathrm{Y}=\mathrm{a}+\mathrm{b}\left(1-\exp ^{-\mathrm{t} t}\right)$. The $\mathrm{CP}, \mathrm{NDF}, \mathrm{ADF}$ and $\mathrm{CT}$ content of sainfoin hay ranged from 11.39-17.70, 43.31-47.64, 35.61-43.30 and 4.19-9.95\%, respectively. The sainfoin obtained from Afsin and Baskonus had significantly ( $\mathrm{p}<0.001)$ higher crude protein contents than those of sainfoin hays from Tekir, Pazarcik and Kapicam. The NDF content of sainfoin hay obtained from Pazarcik and Kapicam was significantly $(\mathrm{p}<0.001)$ higher than those of sainfoin hays from Afsin and Tekir the ADF content of sainfoin hay from Kapicam was significantly $(\mathrm{p}<0.001$ ) higher than those of sainfoin hays from Afsin, Tekir, Pazarcik and Baskonus. The CT content of sainfoin hay from Pazarcik was significantly $(\mathrm{p}<0.001)$ higher than those of sainfoin hays from Afsin, Tekir, Baskonus and Kapicam. The gas production from slowly soluble fraction of sainfoin hay from Afsin was significantly $(\mathrm{p}<0.001)$ higher than those of sainfoin hays from Tekir and Kapicam. The ME and OMD ranged from 6.86-7.79 $\mathrm{MJ} \mathrm{kg}^{-1} \mathrm{DM}, 47.82-53.17 \%$, respectively. The $\mathrm{ME}$ and $\mathrm{OMD}$ content of sainfoin hay from Afsin was significantly $(\mathrm{p}<0.001)$ higher than those of sainfoin hays from Tekir and Kapicam. As a conclusion, the growing site had a significant effect on the chemical composition in vitro gas production, $\mathrm{ME}$ and $\mathrm{OMD}$ of sainfoin hay harvested at flowering stage. There are considerable variations in chemical composition of sainfoin hay harvested at flowering stages among growing sites. The $\mathrm{ME}$ and $\mathrm{OMD}$ values of sainfoin hay are negatively correlated with cell wall and CT contents but positively correlated with CP content.
\end{abstract}

Key words: Potential nutritive value, forage, in vitro gas production, tannin, sainfoin hay, Turkey

\section{INTRODUCTION}

Native pasture is a very important in providing forages for ruminant animals in Mediterranean areas. The legume plants in native pasture are one of the very important components of pasture since they are rich in protein. Sainfoin is one of the perennial legume plants in native pasture in Turkey. Sainfoin is preferable to alfalfa due to due to its forage quality (Carleton et al., 1968). Sainfoin is also preferable to alfalfa due to low incidence of bloat (Majak et al., 1995). It was also suggested that tannin containing legume hays such as sainfoin (Onobrychis viciaefolia) offer an alternative to anthelmintic chemicals to control gastrointestinal nematodes (Brunet et al., 2008). Although, sainfoin (Onobrychis viciaefolia) is one of the important perennial legume plants in Mediterranean wild pastures due to excellent nutritional and palatability properties there is limited research on the wild sainfoin hays obtained from different growing sites.
Recently some researches have used the in vitro gas production technique to evaluate the fermentation kinetics of ruminant feedstuffs (Mesgaran and Mohammadabadi, 2010; Mesgaran et al., 2010; Chaji et al., 2010; Kamalak, 2010). Therefore, the aim of this study was to determine the potential nutritive value of Sainfoin (Onobrychis viciaefolia) hays harvested at flowering stage from five different growing sites using chemical composition and in vitro gas production technique.

\section{MATERIALS AND METHODS}

Hay samples: In the present study, sainfoin (Onobrychis viciaefolia) hays from five different growing sites (Afsin, Tekir, Pazarcik, Baskonus and Kapicam) were hand harvested from native pasture at flowering stage which is common practice in Turkey for hay production. The hay samples were shade-dried and milled to pass through a $1 \mathrm{~mm}$ sieve for subsequent analysis. 
Chemical analysis: Dry matter content was determined by drying the samples at $105^{\circ} \mathrm{C}$ overnight and the ash by igniting the samples in a muffle furnace at $525^{\circ} \mathrm{C}$ for $8 \mathrm{~h}$. Nitrogen $(\mathrm{N})$ content was measured by the Kjeldahl method (AOAC, 1990). The CP was calculated as $\mathrm{N} \times 6.25$. The Neutral Detergent Fiber (NDF) and Acid Detergent Fiber $(\mathrm{ADF})$ of sainfoin hay sample were analyzed with the ANKOM fiber analyzer using reagents described by Van Soest (1963) and Van Soest and Robertson (1985), respectively. Condensed tannin contents were determined by butanol-HCl method as described by Makkar et al. (1995). All chemical analyses were carried out in duplicate.

In vitro gas production: Sainfoin hay samples milled through a $1 \mathrm{~mm}$ sieve were incubated in vitro rumen fluid in glass bottles following the procedures of Theodorou et al. (1994). Rumen fluid was obtained from three fistulated sheep fed twice daily with a diet containing alfalfa hay $(60 \%)$ and concentrate $(40 \%)$. Approximately $0.200 \mathrm{~g}$ dry weight of samples was incubated in a glass bottle of $100 \mathrm{~mL}$ containing $50 \mathrm{~mL}$ of McDougall's buffer/rumen mixture in triplicate. Gas production was determined at $3,6,12,24,48,72$ and $96 \mathrm{~h}$ after incubation using pressure transducer. Total gas production was corrected for blank gas production. The in vitro gas production kinetics was estimated using the exponential model:

Where:

$$
y=a+b\left(1-e^{-c t}\right)
$$

$\mathrm{y}=$ Gas produced at time $\mathrm{t}$

$\mathrm{a}=$ The gas production from the quickly soluble fraction $(\mathrm{mL})$

$\mathrm{b}=$ The gas production from the slowly degradable fraction $(\mathrm{mL})$

$\mathrm{c}=$ The gas production rate constant for the slowly degradable fraction $(\mathrm{b})$

$\mathrm{t}=$ Incubation time $(\mathrm{h})$

$\mathrm{ME}\left(\mathrm{MJ} \mathrm{kg}{ }^{-1} \mathrm{DM}\right.$ ) content of samples was calculated using equation of Menke et al. (1979) as follows:

$$
\mathrm{ME}\left(\mathrm{MJ} \mathrm{kg}^{-1} \mathrm{DM}\right)=2.20+0.136 \mathrm{GP}+0.057 \mathrm{CP}
$$

Where:

$\mathrm{GP}=24 \mathrm{~h}$ net gas production $(\mathrm{mL} / 200 \mathrm{mg})$

$\mathrm{CP}=$ Crude Protein

Organic matter digestibility (\%) of samples was calculated using equation of Menke et al. (1979) as follows:

$$
\mathrm{OMD}(\%)=14.88+0.889 \mathrm{GP}+0.45 \mathrm{CP}+0.0651 \mathrm{XA}
$$

Where, XA is ash content $(\%)$.

\section{RESULTS AND DISCUSSION}

The chemical composition of sainfoin hay from different growing sites harvested at flowering stage is shown in Table 1 . The growing site had a significant effect on the chemical composition of sainfoin hay harvested at flowering stage. The $\mathrm{CP}$ content of sainfoin hay ranged from $11.39-17.70 \%$. The sainfoin obtained from Afsin and Baskonus had significantly $(\mathrm{p}<0.001)$ higher crude protein contents than those of sainfoin hays from Tekir, Pazarcik and Kapicam. Although, the NDF content of sainfoin hay obtained from Pazarcik and Kapicam was significantly $(\mathrm{p}<0.001)$ higher than those of sainfoin hays from Afsin and Tekir the $\mathrm{ADF}$ content of sainfoin hay from Kapicam was significantly $(\mathrm{p}<0.001)$ higher than those of sainfoin hays from Afsin, Tekir, Pazarcik and Baskonus. The CT content of sainfoin hay from Pazarcik was significantly $(\mathrm{p}<0.001)$ higher than those of sainfoin hays from Afsin, Tekir, Baskonus and Kapicam. The chemical composition of sainfoin hay obtained in the current study was consisted with findings of Bal et al. (2006). It was reported that the growing site had an effect on the condensed tannin contents of shrub and tree leaves (Ozturk et al., 2006). Tannins may form a less digestible complex with dietary proteins and may bind and inhibit the endogenous protein such as digestive enzymes (Kumar and Singh, 1984) and microbial enzyme (Singleton, 1981; Lohan et al., 1983; Barry et al., 1984; Makkar et al., 1989). CT content of forages in the range of $60-100 \mathrm{~g} \mathrm{~kg}^{-1} \mathrm{DM}$ depresses intake and growth of animals (Barry et al., 1984). CT contents of sainfoin hay obtained from Afsin and Tekir were lower than this range whereas CT contents of sainfoin hays obtained from Pazarcik, Baskonus and Kapicam were within this range. Therefore, supplementation of Polyethylene Glycol (PEG) or other alkali can be recommended to reduce the possible detrimental effect of condensed tannin on feed intake.

\begin{tabular}{|c|c|c|c|c|c|c|c|}
\hline \multirow[b]{2}{*}{ Composition } & \multicolumn{7}{|l|}{ Sites } \\
\hline & Afsin & Tekir & Pazarcik & Baskonus & Kapicam & SEM & Sig. \\
\hline$\overline{\mathrm{DM}}$ & $94.67^{c}$ & $95.10^{c}$ & $95.73^{\mathrm{a}}$ & $95.58^{\mathrm{a}}$ & $95.40^{\mathrm{ab}}$ & 0.155 & ******* \\
\hline $\mathrm{CP}$ & $17.39^{a}$ & $15.23^{b}$ & $15.16^{b}$ & $17.70^{\mathrm{a}}$ & $11.39^{c}$ & 0.169 & * * *k: \\
\hline $\mathrm{NDF}$ & $43.31^{b}$ & $43.56^{b}$ & $47.64^{\mathrm{a}}$ & $44.61^{a b}$ & $47.59^{\mathrm{a}}$ & 0.945 & *w*tw \\
\hline $\mathrm{ADF}$ & $35.62^{c}$ & $35.61^{\mathrm{c}}$ & $38.28^{b}$ & $34.34^{c}$ & $43.30^{\mathrm{a}}$ & 0.521 & **w** \\
\hline Ash & $5.97^{\mathrm{bc}}$ & $7.30^{\mathrm{a}}$ & $5.21^{\mathrm{d}}$ & $6.40^{\mathrm{b}}$ & $5.61^{c}$ & 0.137 & *w*w \\
\hline CT & $4.19^{c}$ & $5.76^{b c}$ & $9.95^{\mathrm{a}}$ & $6.59^{b}$ & $6.82^{b}$ & 0.500 & ******** \\
\hline
\end{tabular}

Table 1: The chemical composition of sainfoin hay from different growing sites harvested at flowering stage

a-cRow means with common superscripts do not differ $(p>0.05)$, SEM: Standard Error Mean; Sig: Significance level; DM: Dry Matter, CP: Crude Protein, NDF: Neutral Detergent Fiber, ADF: Acid Detergent Fiber, CT: Condensed Tannin 


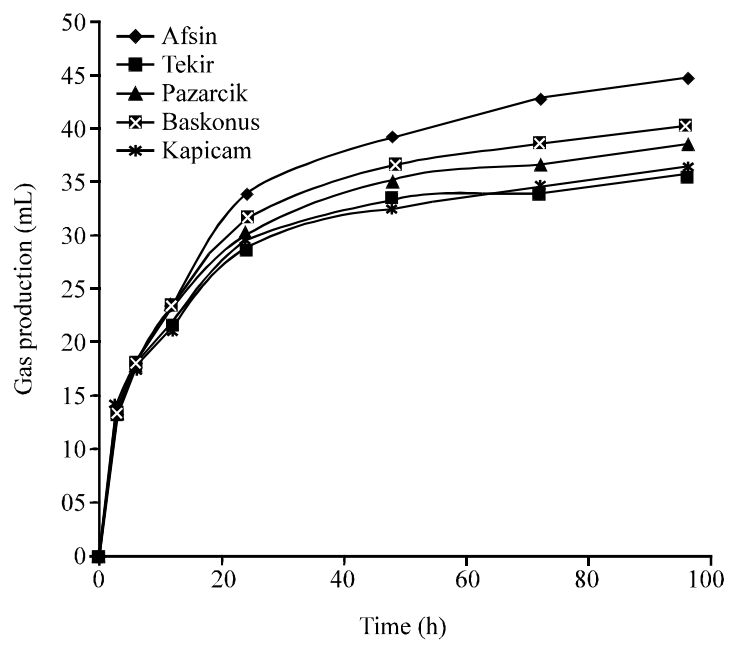

Fig. 1: In vitro gas production of sainfoin hay from different growing sites harvested at flowering stage

The in vitro gas production of sainfoin hay from different growing sites harvested at flowering stage is shown in Fig. 1. After $24 \mathrm{~h}$ incubation times the in vitro gas production of sainfoin hay from Afsin was significantly $(p<0.001)$ higher than those of sainfoin hays from Tekir, Pazarcik, Baskonus and Kapicam.

The fermentation kinetics, metabolisable energy and organic matter digestibility of sainfoin hay from different growing sites harvested at flowering stage is shown in Table 2. The growing site had a significant effect on the fermentation kinetics, metabolisable energy and organic matter digestibility of sainfoin hay harvested at flowering stage. The gas production rate of sainfoin obtained from Tekir and Kapicam was significantly $(p<0.001)$ higher than that of sainfoin hay from Afsin. The gas production from quickly soluble fraction of sainfoin from Afsin was significantly $(p<0.001)$ higher than those of sainfoin hay from Tekir, Pazarcik and Baskonus. The gas production from slowly soluble fraction of sainfoin hay from Afsin was significantly $(p<0.001)$ higher than those of sainfoin hays from Tekir and Kapicam. The ME and OMD content of sainfoin hay from Afsin was significantly $(\mathrm{p}<0.001)$ higher than those of sainfoin hays from Tekir and Kapicam.

Generally the ME, OMD, gas production and their kinetics except for $\mathrm{c}$ and a obtained in the current study were considerably lower than those reported by Bal et al. (2006). The differences between these two studies are possibly due to differences in buffered solution used in these two experiments.

Correlation coefficient (r) relationship of chemical composition with gas production kinetics and some estimated parameters are shown in Table 3. The b, ME
Table 2: The fermentation kinetics, metabolisable energy and organic matter digestibility of sainfoin hay from different growing sites harvested at flowering stage Sites

Parameters Afsin Tekir Pazarcik Baskonus Kapicam SEM Sig. \begin{tabular}{llllllll}
\hline c & $0.066^{b}$ & $0.095^{\mathrm{a}}$ & $0.086^{\mathrm{ab}}$ & $0.088^{\mathrm{ab}}$ & $0.093^{\mathrm{a}}$ & 0.007 & ******
\end{tabular} $\begin{array}{llllllll}\text { a } & 3.260^{\mathrm{a}} & 2.090^{\mathrm{b}} & 2.410^{\mathrm{b}} & 2.460^{\mathrm{b}} & 2.650^{\mathrm{ab}} & 0.196\end{array}$ *秘水

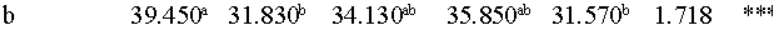

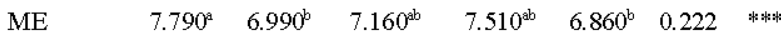
$\begin{array}{lllllll}\text { OMD } & 53.170^{\mathrm{a}} & 47.820^{\text {bc }} & 48.860^{\mathrm{abc}} & 51.410^{\mathrm{ab}} & 46.600^{c} & 1.452\end{array}$ ****:

${ }^{a-c}$ Row means with common superscripts do not differ ( $>0.05$ ), SEM: Standard Error Mean; Sig: Significance level; $a=$ the gas production from the quickly soluble fraction $(\mathrm{mL}), \mathrm{b}=$ the gas production from the slowly degradable fraction $(\mathrm{mL}), \mathrm{c}=$ the gas production rate constant for the slowly degradable fraction (b), ME: Metabolisable Energy, MJ kg-1 DM, OMD: Organic Matter Digestibility (\%), **** $\mathrm{p}<0.001$

Table 3: Correlation coefficient (r) relationship of chemical composition with gas production kinetics and some estimated parameters

\begin{tabular}{lllllc}
\hline Parameters & ADF & NDF & Ash & CP & CT \\
\hline c & $0.327^{\mathrm{NS}}$ & $0.354^{\mathrm{NS}}$ & $0.282^{\mathrm{NS}}$ & $-0.555^{*}$ & $0.574^{*}$ \\
$\mathrm{a}$ & $0.047^{\mathrm{NS}}$ & $-0.159^{\mathrm{NS}}$ & $-0.422^{\mathrm{NS}}$ & $0.210^{\mathrm{NS}}$ & $-0.545^{*}$ \\
$\mathrm{~b}$ & $-0.547^{*}$ & $-0.444^{\mathrm{NS}}$ & $-0.159^{\mathrm{NS}}$ & $0.769^{* * * *}$ & $-0.451^{\mathrm{NS}}$ \\
$\mathrm{ME}$ & $-0.661^{* * * *}$ & $-0.523^{*}$ & $-0.027^{\mathrm{NS}}$ & $0.853^{* * * *}$ & $-0.422^{\mathrm{NS}}$ \\
OMD & $-0.695^{* * *}$ & $-0.543^{*}$ & $0.007^{\mathrm{NS}}$ & $0.877^{* * * *}$ & $-0.412^{\mathrm{NS}}$ \\
\hline
\end{tabular}

ADF: Acid Detergent Fiber, NDF: Neutral Detergent Fiber, CP: Crude Protein, CT: Condensed Tannin; $\mathrm{a}=$ the gas production from the quickly soluble fraction $(\mathrm{mL}), \mathrm{b}=$ the gas production from the slowly degradable fraction $(\mathrm{mL}), \mathrm{c}=$ the gas production rate constant for the slowly degradable fraction (b), ), ME: Metabolisable Energy, $\mathrm{MJ} \mathrm{kg}^{-1} \mathrm{DM}$, OMD:Organic Matter Digestibility (\%), NS: Non-Significant, * $p<0.05$, *** $p<0.001$

and $\mathrm{OMD}$ were negatively correlated with cell wall contents (ADF and NDF) whereas they were positively correlated with CP content. This result is in agreement with findings of Kamalak (2006).

The gas production is associated with volatile fatty acid production after fermentation of carbohydrate in feedstuffs (Blummel an Orskov, 1993). The increase in cell wall content of sainfoin hay might have resulted in a decrease in fermentable carbohydrate. As a result of decrease in fermentable fraction of sainfoin hay, the production of VFA acid decreased which means that less gas production occurred from slowly fermentable fraction (b). The estimated ME and OMD values were decreased with decreasing gas production due to increase in less fermentable cell wall contents of sainfoin hay since the $\mathrm{ME}$ and $\mathrm{OMD}$ were estimated from chemical compositions and gas production at $24 \mathrm{~h}$ incubation time.

\section{CONCLUSION}

The growing site had a significant effect on the chemical composition, in vitro gas production, $\mathrm{ME}$ and $\mathrm{OMD}$ of sainfoin hay harvested at flowering stage. There are considerable variations in chemical composition of sainfoin hay harvested at flowering stages among growing sites. The $\mathrm{ME}$ and $\mathrm{OMD}$ values of sainfoin hay are negatively correlated with cell wall and CT contents but positively correlated with CP content. 


\section{REFERENCES}

AOAC, 1990. Official Methods of Analysis. Association of Official Analytical Chemists, Washington, DC. USA., pp: 69-88.

Bal, M.A., D. Ozturk, R. Aydin, A. Erol, C.O. Ozkan, M. Ata, E. Karakas and P. Karabay, 2006. Nutritive value of sainfoin (Onobrychis viciaefolia) harvested at different maturity stages. Pak. J. Biol. Sci., 9: 205-209.

Barry, T.N., T.R. Manley and J.S. Duncan, 1984. The role of condensed tannins in the nutritional value of Lotus pedunculatus for sheep intake. Br. J. Nutr., 51: 485-491.

Blummel, M. and E.R. Orskov, 1993. Comparison of in vitro gas production and nylon bag degradability of roughages in predicting feed intake in cattle. Anim. Feed Sci. Technol., 40: 109-119.

Brunet, S., F. Jackson and H. Hoste, 2008. Effects of sainfoin (Onobrychis viciifolia) extract and monomers of of abomasal nematode larvae with fundic explants. Inter. J. Parasit., 38: 783-790.

Carleton, A.E., C.S. Cooper, R.H. Delaney, A.L Dubbs and R.F. Eslick, 1968. Growth and forage quality comparison of sainfoin (Onobrychis viciaefolia Scop.) and alfalfa (Medicago sativa L.). Agron. J., 60: 630-632.

Chaji, M., T. Mohammadabadi, M. Mamouei and S. Tabatabaei, 2010. The effect of processing with high steam and sodium hydroxide on nutritive value of sugarcane pith by in vitro gas production. J. Anim. Vent. Adv., 9: 1015-1018.

Kamalak, A., 2006. Determination of nutritive value of leaves of a native grown shrub, Glycyrrhiza glabra L. using in vitro and in situ measurements. Small Rum. Res., 64: 268-278.

Kamalak, A., 2010. Determination of potential nutritive value of Polygonum aviculare hay harvested at three maturity stages. J. Applied Anim. Res., 38: 69-71.

Kumar, R. and M. Singh, 1984. Tannins: Their adverse role in ruminant nutrition. J. Agric. Food Chem., 32: $447-453$.

Lohan, O.P., D. Lall, J. Vaid and S.S. Negi, 1983. Utilization of oak tree fodder in cattle ration and fate of oak leaf tannins in the ruminant system. Ind. J. Anim. Sci., 53: $1057-1063$.
Majak, W., J.W. Hall and W.P. McCaughey, 1995. Pasture management strategies for reducing the risk of legume bloat in cattle. J. Anim. Sci., 73: 1493-1498.

Makkar, H.P.S., B. Singh and S.S. Negi, 1989. Relationship of rumen degradability with microbial colonization, cell wall constituents and tannin levels in some tree leaves. Anim. Prod. Sci., 49: 299-303.

Makkar, H.P.S., M. Blummel and K. Becker, 1995. Formation of complexes between polyvinyl pyrrolidones or polyethylene glycols and their implication in gas production and true digestibility in vitro techniques. Br. J. Nutr., 73: 897-913.

Menke, K.H., L. Raab, A. Salewski, H. Steingass, D. Fritz and W. Schneider, 1979. The estimation of digestibility and metabolizable energy content of ruminant feedstuffs from the gas production when they incubated with rumen liquor in vitro. J. Agric. Sci. Camb., 92: 217-222.

Mesgaran, M.D. and T. Mohammadabadi, 2010. The effect of fat content of chemically treated sunflower meal on in vitro gas production parameters using isolated Rumen microbiota. J. Anim. Vet. Adv., 9: 2466-2471. Mesgaran, M.D., M. Malakkhahi, A.R.H. Moussavi, A. Vakili and A. Tahmasbi, 2010. In situ ruminal degradation and in vitro gas production of chemically treated sesame stover. J. Anim. Vet. Adv., 9: $2256-2260$.

Ozturk, D., C.O. Ozkan, A.I. Atalay and A. Kamalak, 2006. The effect of species and site on the condensed tannin content of shrub and tree leaves. Res. J. Anim. Vet. Adv., 1: 41-44.

Singleton, V.L., 1981. Naturally occurring food toxicants: Phenolic substances of plant origin common in foods. Adv. Food. Res., 27: 149-242.

Theodorou, M.K., B.A. Williams, M.S. Dhanoa, A.B. McAllan and J. France, 1994. A simple gas production method using a pressure transducer to determine the fermentation kinetics of ruminant feeds. J. Anim. Feed Sci. Technol., 48: 185-197.

Van Soest, P.J. and J.B. Robertson, 1985. A Laboratory Manual for Animal Science. Ithaca, Cornell University, New York.

Van Soest, P.J., 1963. Use of detergents in the analysis of fibrous feeds. II. A rapid method for the determination of fibre and lignin. J. Assoc. Official Agric. Chemists J., 46: 829-835. 